\title{
Influence of HFM Thermal Contact on the Accuracy of In Situ Measurements of Façades' U-Value in Operational Stage
}

\author{
Katia Gaspar*iD, Miquel Casals and Marta Gangolells \\ Group of Construction Research and Innovation (GRIC), Universitat Politècnica de \\ Catalunya·BarcelonaTech (UPC), C/Colom, 11, Ed. TR5, 08222 Terrassa, Spain; miquel.casals@upc.edu (M.C.); \\ marta.gangolells@upc.edu (M.G.) \\ * Correspondence: katia.gaspar@upc.edu
}

check for updates

Citation: Gaspar, K.; Casals, M.; Gangolells, M. Influence of HFM Thermal Contact on the Accuracy of In Situ Measurements of Façades' U-Value in Operational Stage. Appl. Sci. 2021, 11, 979. https://doi.org/10.3390/ app11030979

Academic Editor: Jerzy Hoła Received: 30 November 2020 Accepted: 18 January 2021 Published: 22 January 2021

Publisher's Note: MDPI stays neutral with regard to jurisdictional claims in published maps and institutional affiliations.

Copyright: (c) 2021 by the authors. Licensee MDPI, Basel, Switzerland. This article is an open access article distributed under the terms and conditions of the Creative Commons Attribution (CC BY) license (https:// creativecommons.org/licenses/by/ $4.0 /)$.
Abstract: Accurate information on the actual thermal transmittance of walls is vital to select appropriate energy-saving measures in existing buildings to meet the commitments of the European Green Deal. To obtain accurate results using the heat flow meter (HFM) method, good thermal contact must be made between the heat flow meter plate and the wall surface. This paper aimed to assess the influence of the non-perfect thermal contact of heat flow meter plates on the accuracy of in situ measurement of the façades' U-value when a film was applied to avoid damage to the wall surface. Given the fact that to avoid harm to the wall surface, the laying of a film is a usual procedure in the installation of equipment during the building's operational stage. The findings show that deviations between measured U-values when an HFM was installed directly on the wall surface and when an HFM was installed with a PVC film were found to differ significantly from the theoretical effect of including a PVC film during the monitoring process.

Keywords: non-destructive test; monitoring; housing; buildings; façade; thermal transmittance; HFM method

\section{Introduction}

Efficiency in terms of energy and resources is required by the European Green Deal when building and renovating the European building stock [1] for achieving the European Union's energy efficiency targets [2]. To meet the 2050 long-term climate and energy targets, $97 \%$ of the residential building stock, which is responsible for around $36 \%$ of $\mathrm{CO}_{2}$ emissions in the European Union [3], needs to be upgraded to become highly energy efficient and obtain the Energy Performance Certificate (EPC) label A [4]. This high percentage is due partly to the average age of European residential building stock: more than $80 \%$ of residential buildings are over 25 years old (Table 1) and, therefore, most of them were built without thermal regulation. Construction is considered the sector with the most potential for energy saving. Buildings represent $40 \%$ of the energy used in the European Union [5]. Almost 26\% of Europe's total final energy consumption is used in residential buildings [6]. Space heating represents a large amount of energy consumption in the housing sector $[7,8]$ and, therefore, has a significant capacity for energy saving.

Table 1. Distribution of residential floor space by year of construction in the European Union 27, Switzerland and Norway [9].

\begin{tabular}{ccccc}
\hline \multirow{2}{*}{ Region } & Floor Space & \multicolumn{2}{c}{ Average Age of Residential Floor Space } \\
\cline { 3 - 5 } & Distribution & Pre 1960 & $\mathbf{1 9 6 1 - 1 9 9 0}$ & $\mathbf{1 9 9 1 - 2 0 1 0}$ \\
\hline North and West & $50 \%$ & $42 \%$ & $39 \%$ & $19 \%$ \\
Central and East & $14 \%$ & $35 \%$ & $48 \%$ & $17 \%$ \\
South & $36 \%$ & $37 \%$ & $49 \%$ & $14 \%$ \\
\hline
\end{tabular}


According to the IEA EBC Annex 71-project [10], measuring the actual energy performances discloses a notable gap between actual and expected energy performances of buildings. The actual thermal behaviour of building envelopes could contribute to this energy performance gap in buildings. Deviations between the predicted and actual behaviour of envelopes are related to aspects of the design and construction stages [11]. Moreover, assumptions about energy efficiency improvements resulting from building refurbishment are not always met [12,13]. Consequently, accurate in situ measurements of the actual U-value of façades are necessary.

The thermal performance of building façades is a fundamental parameter that should be evaluated to obtain an accurate energy diagnosis of buildings [14-21]. Successful decision-making during energy renovation processes of existing buildings requires precise characterization of thermal properties of building components [22,23]. Classifying the opaque part of the façades is essential to precisely analyse the thermal performance of façades in the housing sector.

In recent years, the thermal behaviour of the materials that compose façades had been studied in depth by several authors such as Laaroussi et al. [24] measuring the thermal properties of brick materials, Kuman and Suman [25] or Björk and Enochsson [26] measuring the properties of thermal insulation materials. However, when analysing the thermal transmittance of walls, assumed U-values have been a meaningful source of error in estimations of energy savings and carbon emissions [27]. Evidence suggests that assumptions concerning heat loss from a dwelling pre-retrofit and post-retrofit are not correct [12]. Therefore, accurate on-site measurements are required to provide information on the actual thermal transmittance of façades. To effectively quantify the actual performance of buildings, optimized on-site measurements combined with dynamic data analysis techniques are needed [28].

Several methods can be used for the in situ measurement of U-value of existing buildings' façades $[29,30]$. One of the most common is the heat flow meter method, standardised by ISO 9869-1:2014 [31]. This method obtains the thermal transmittance by measuring the heat flow rate that passes through a wall and the inside and outside environmental temperatures. However, difficulties can arise in on-site measurements of walls U-value in the existing building stock, leading to inaccuracies [32]. These difficulties can be classified into three groups, according to the IEA EBC Annex 58-project [33]: errors related to the measurement accuracy, errors related to the analysis of data and errors related to the boundary conditions of the in situ measurement. Difficulties related to the measurement accuracy include factors like reading and calibration of heat flow meters and temperature sensors and had been deeply analysed by authors such as Ficco et al. [17], Trethowen [34] and Meng et al. [35]. Difficulties related to the analysis of data were recently analysed in depth [32,36-39]. Difficulties related to the boundary conditions include factors as an imbalance of the heat flow, edge heat loss and accuracy on the position of sensors, which were highly analysed by Peng and Wu [32], Meng et al. [35], Cesaratto et al. [40], Ahmad et al. [41] and Guattari et al. [42]. Delving into boundary monitoring conditions, the factor of contact between the wall surface and the heat flow meter was analysed by simulations but has not been analysed in experimental tests [40], so as for the present study focuses on this aspect.

The IEA EBC Annex 58-project [33] and authors such as Cesaratto et al. [40], Tadeu et al. [43] and Gori and Elwell [44] highlight the importance of ensuring good thermal contact between the heat flow meter plate and the wall to be measured to obtain accurate results. However, conducting HFM in situ measurements during the operational stage of dwellings is challenging due to the need for avoiding damage to wall surfaces. In this sense, the usual practice is placing a PVC film to preserve the wall surface $[27,45]$.

Considering all the aspects aforementioned, the study aimed to analyse the influence of the non-perfect thermal contact of heat flow meter plates on the accuracy of in situ measurement of the façades' U-value when a film was applied to avoid damage to the wall surface, as a usual equipment installation procedure during the building's operational 
stage. This research provides valuable additional evidence on the accuracy of in situ monitoring of the actual U-value of existing buildings' façades and will therefore assist practitioners in pre-retrofit diagnosis.

The method used to analyse the influence of the non-perfect thermal contact of heat flow meter plates on the accuracy of in situ measurement of the façades' U-value is explained in the second section following this introduction. The third section presents the results. Finally, the discussion and conclusions are given in the fourth section.

\section{Materials and Methods}

\subsection{Methodology}

The method for assessing the impact of the heat flow meter thermal non-perfect contact on the accuracy of in situ measurement of walls U-value consists of three steps (Figure 1):

- First, two façades with a range of theoretical thermal transmittance values were selected.

- Second, in situ measurements of walls' U-value were conducted with two heat flow meters. One heat flow meter was installed by applying a layer of interface material between the heat flow meter and the wall surface, and the other heat flow meter was installed by applying a PVC film between the layer of interface material and the wall surface. During the monitoring process, recommendations on apparatus and environmental conditions were considered [31]. Then, data were analysed using the dynamic method.

- Third, the variability of results was analysed by comparing the differences between the measured thermal transmittances obtained from the two heat flow meters with the theoretical effect of including a PVC film during the monitoring process, for the two case studies.

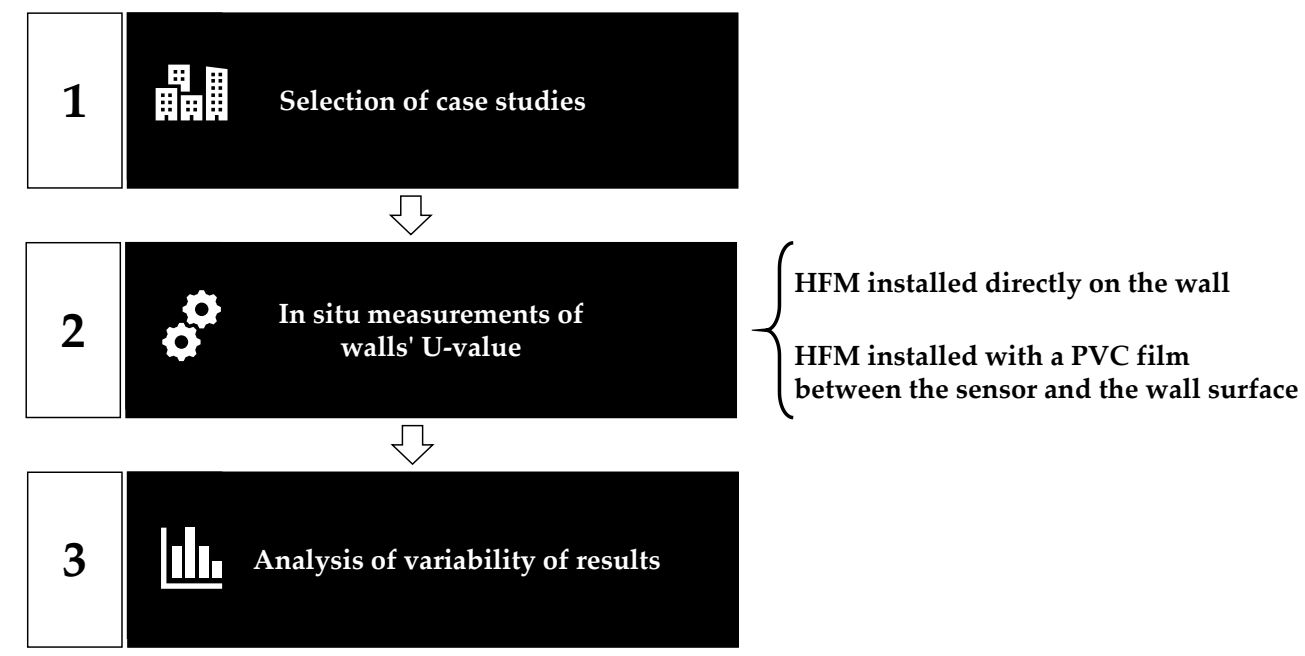

Figure 1. Research methodology.

\subsection{Case Studies}

To analyse the implications of using a protective film during the installation process of heat flow meters on the accuracy of in situ measurements of the façades' thermal transmittance, two brick masonry walls with varying theoretical thermal transmittances were selected as case studies (Case studies 1 and 2).

Case study 1 was built in 1960 and according to Gaspar et al. [46] can be defined as a single-skin wall with no air cavity or insulation. This case study is located between an interior habitable zone and an interior non-habitable zone. Case study 2 was built in 2005 , it is a double-skin façade with internal insulation but no air cavities finished with 
continuous covering [46]. This case study is located between an indoor habitable zone and an outdoor zone.

The theoretical total thermal resistance $(R T)$ of the two multilayer walls can be calculated as follows [47]:

$$
R_{T}\left(\frac{\mathrm{m}^{2} \cdot \mathrm{K}}{W}\right)=\frac{1}{U_{t}}=R_{s i}+R_{1}+R_{2}+\ldots+R_{N}+R_{s e}
$$

where $U_{t}$ is the theoretical thermal transmittance of the wall, $R_{s i}$ and $R_{s e}$ are the internal and external superficial resistance values $\left(0.13 \mathrm{~m}^{2} \cdot \mathrm{K} / \mathrm{W}\right.$ and $0.04 \mathrm{~m}^{2} \cdot \mathrm{K} / \mathrm{W}$, respectively [47]) and $R_{1}+R_{2}+\ldots+R_{N}$ are the design thermal resistance values for layers from 1 to $\mathrm{N}$.

To calculate the design thermal resistance $(R)$ of a uniform layer, the following expression was used:

$$
R\left(\frac{\mathrm{m}^{2} \cdot \mathrm{K}}{W}\right)=\frac{d}{\lambda}
$$

where $d$ is the thickness of the layer and $\lambda$ is its design thermal conductivity.

Design data to calculate the designed thermal transmittance was obtained from the buildings' executive projects and reports. This information was corroborated by the facility managers of the buildings. Subsequently, the thickness of the wall was measured on-site. The theoretical U-values of the two case studies were determined according to Equations (1) and (2), following guidelines of ISO 6949:2007 [47] and the Spanish Technical Building Code's Catalogue of Building Elements [48]. Even though the theoretical U-values were not absolutely certain were taken as reference values. Table 2 provides a summary of the thickness, thermal conductivity and thermal resistance of each layer and the theoretical thermal transmittance for the case studies.

\begin{tabular}{|c|c|c|c|c|c|c|c|}
\hline Case Study & No. Layer & $\begin{array}{l}\text { Material Layer } \\
\text { (Inside-Outside) }\end{array}$ & Thickness (m) & $\begin{array}{c}\text { Thermal } \\
\text { Conductivity } \\
(\mathrm{W} / \mathrm{m} \cdot \mathrm{K})\end{array}$ & $\begin{array}{c}\text { Thermal } \\
\text { Resistance } \\
\left(\mathrm{m}^{2} \cdot \mathrm{K} / \mathrm{W}\right)\end{array}$ & $\begin{array}{c}\text { Total } \\
\text { Thickness } \\
\text { (m) }\end{array}$ & $\begin{array}{c}\text { Theoretical } \\
\text { U-Value } \\
\left(\mathrm{W} / \mathrm{m}^{2} \cdot \mathrm{K}\right)\end{array}$ \\
\hline \multirow{5}{*}{ Case study 1} & & & & & 0.13 & \multirow{5}{*}{0.12} & \multirow{5}{*}{2.20} \\
\hline & 1 & Mortar plaster & 0.01 & 0.570 & 0.018 & & \\
\hline & 2 & Hollow brick wall & 0.10 & & 0.160 & & \\
\hline & 3 & Mortar plaster & 0.01 & 0.570 & 0.018 & & \\
\hline & & & & & 0.13 & & \\
\hline \multirow{7}{*}{ Case study 2} & & & & & 0.13 & \multirow{7}{*}{0.34} & \multirow{7}{*}{0.36} \\
\hline & 1 & Mortar plaster & 0.02 & 1.300 & 0.015 & & \\
\hline & 2 & Hollow brick wall & 0.10 & & 0.160 & & \\
\hline & 3 & $\begin{array}{l}\text { Polyurethane } \\
\text { insulation }\end{array}$ & 0.06 & 0.028 & 2.143 & & \\
\hline & 4 & Perforated brick wall & 0.14 & & 0.210 & & \\
\hline & 5 & $\begin{array}{l}\text { Single-layer mortar } \\
\text { plaster }\end{array}$ & 0.02 & 0.340 & 0.059 & & \\
\hline & & & & & 0.04 & & \\
\hline
\end{tabular}

Table 2. Composition of the case studies.

\subsection{In Situ Measurement of Façades' Thermal Transmittance}

This section specifies the instrumentation and data collection process and the subsequent analysis of data.

\subsubsection{Instrumentation}

Proper instrumentation was carefully selected for the in situ measurement of the actual thermal transmittance of the walls. The apparatus consisted of an internal acquisition system, to which two heat flow plates and an internal environmental temperature sensor 
were connected, and an external environmental temperature sensor with its acquisition system. Table 3 summarises the main specifications and a priori accuracy of the calibrated instrumentation.

Table 3. Main specifications of the instrumentation.

\begin{tabular}{cccc}
\hline Type of Equipment & Model and Manufacturer & Range & A Priori Accuracy \\
\hline Heat flow meter plates & HFP01, Hukseflux & $\pm 2000 \mathrm{~W} / \mathrm{m}^{2}$ & $\pm 5 \%$ \\
\hline $\begin{array}{c}\text { Inside environmental } \\
\text { temperature sensor }\end{array}$ & T107, Campbell Scientific, Inc. & $-35^{\circ}$ to $+50{ }^{\circ} \mathrm{C}$ & $\pm 0.5^{\circ} \mathrm{C}$ \\
\hline Inside acquisition system & CR850, Campbell Scientific, Inc. & Input $\pm 5 \mathrm{Vdc}$ & $\pm 0.06 \%$ of reading \\
\hline $\begin{array}{c}\text { Outside environmental } \\
\text { temperature sensor and its } \\
\text { acquisition system }\end{array}$ & 175T1, Instrumentos Testo, SA & $-35^{\circ}$ to $+50{ }^{\circ} \mathrm{C}$ & $\pm 0.5^{\circ} \mathrm{C}$ \\
\hline
\end{tabular}

The monitoring process was designed following ISO guidelines [31]. Taking into account the considerations of Asdrubali et al. [14], Evangelisti et al. [16], Ahmad et al. [41], Tejedor et al. [49,50], Barreira et al. [51] and Nardi et al. [52], the placement of equipment was examined with an infrared thermographic camera (FLIR E60bx Infrared Camera). Proximity to defects, joints and borders of the wall, direct solar radiation and direct impact of heating or cooling devices were avoided, as recommended by Guattari et al. [42] and Evangelisti et al. [53].

The two heat flow meter plates were placed on the inner side of the wall due to it is the location where the temperature was most stable. Proper thermal contact was ensured between the entire area of one heat flow meter plate and the wall surface by carefully applying a layer of thermal interface material. The other heat flow meter plate was meticulously installed by applying a film between the layer of thermal interface material and the wall (Figure 2), which is usual procedure to protect the wall surface, as described in Section 1.

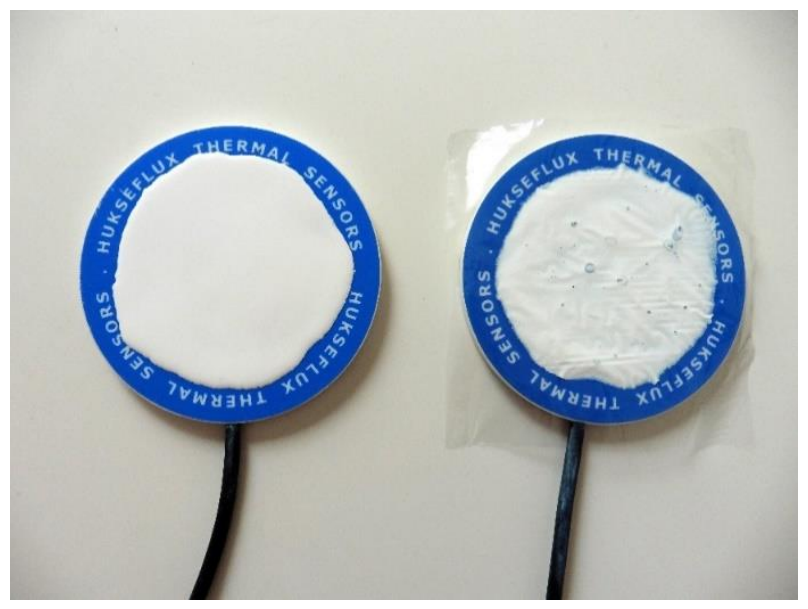

Figure 2. View of two heat flow meter plates, without and with a film between the layer of thermal interface material and the wall surface.

During the experimental campaign, climatic conditions were observed. The monitoring process took into consideration that the internal environmental temperature always exceeded the external environmental temperature, ensuring a stable heat flow direction. Alternating this flow direction could lead to inaccurate measurements, as described by Tadeu et al. [43], and could greatly influence the minimum test duration and the variability of the results [39]. Data were sampled every $1 \mathrm{~s}$ and recorded every 30-min averaged data in both dataloggers. 
Data obtained from process monitoring is depicted in Figure 3, where Tin is the inside environmental temperature, Tout is the outside environmental temperature, $q N F$ is the heat flow measured with a heat flow meter plate installed with direct contact on the wall surface and $q F$ is the heat flow measured with a heat flow meter plate installed by applying a PVC film between the layer of thermal interface material and the wall surface. The experimental campaign of Case study 1 was conducted from 10-17 June 2016 (from 12:00 a.m. to 12:00 a.m.) and of Case study 2 from 24-30 October 2016 (from 12:30 p.m. to 12:30 p.m.).

(a)

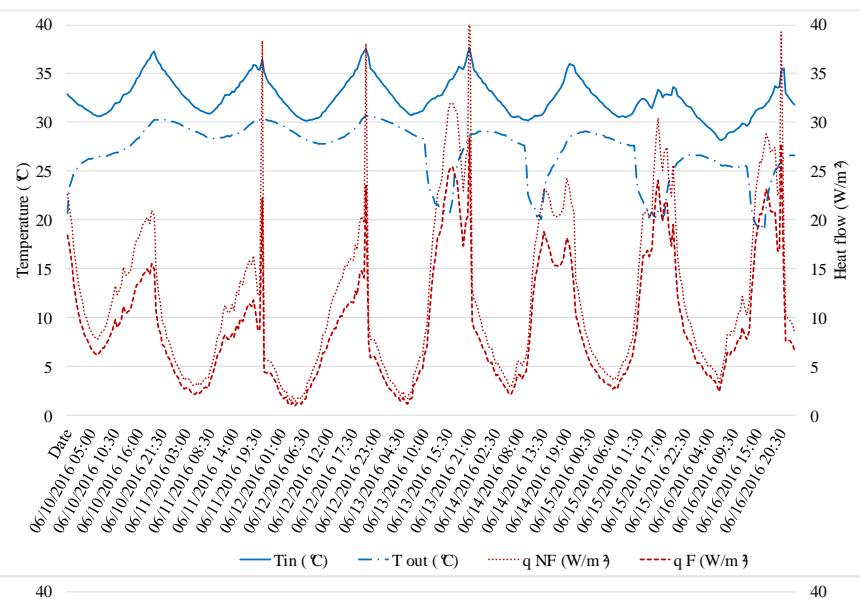

(b)

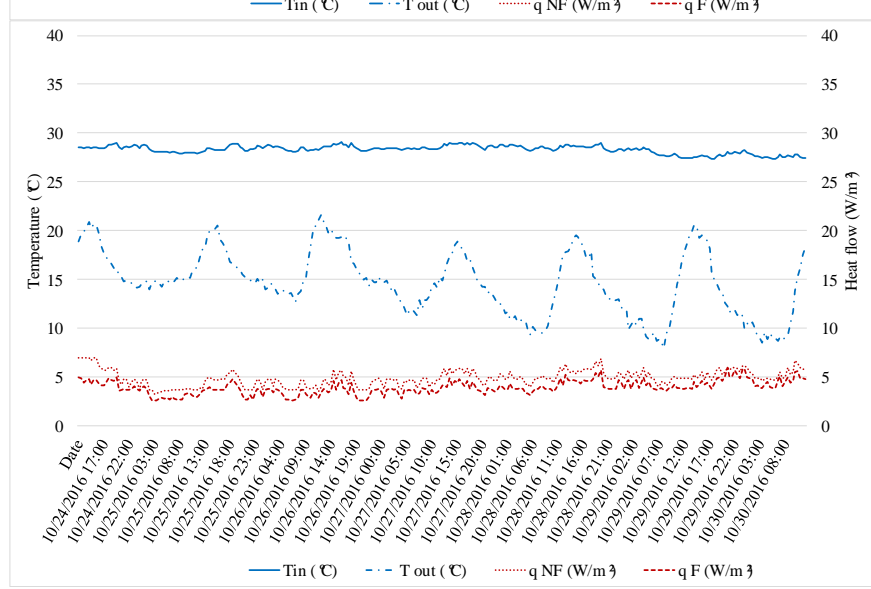

Figure 3. Indoor temperature (Tin), outdoor temperature (Tout), heat flow measured with an heat flow meter (HFM) installed with a layer of thermal interface material directly on the wall surface $(q N F)$ and heat flow measured with an HFM installed with a PVC film between the layer of thermal interface material and the wall surface $(q F)$ for (a) Case study 1 and (b) Case study 2.

\subsubsection{Data Analysis}

The measured thermal transmittance was determined according to the standardised dynamic method described by ISO 9869-1:2014 [31] and extensively detailed in Gaspar et al. [54]. To apply the dynamic analysis, a spreadsheet was programmed following the recommendations of Gaspar et al. [54]. The best estimate of the thermal transmittance was obtained for each cycle of $24 \mathrm{~h}$. A confidence interval of $95 \%$ was adopted in the study to evaluate the quality of the thermal transmittance estimation results [31,55].

The duration of the test was evaluated considering the requirements established in the ISO 9869-1:2014 standard [31,56]. The three requirements are summarised in the following equations (Equations (3)-(5)):

$$
\begin{gathered}
D_{T}(\text { days }) \geq 3 \\
\left|\frac{U_{m i}-U_{m i-1}}{U_{m i-1}} \times 100\right| \leq 5 \%
\end{gathered}
$$




$$
\left|\frac{U_{m_{i=1}^{I N T}\left(2 \times \frac{D T}{3}\right)}^{I}-U_{m}^{D T}}{U_{m_{i=D T}^{D T}-I N T\left(2 \times \frac{D T}{3}\right)+1}^{D T}} \times 100\right| \leq 5 \%
$$

where $D T$ is the length of the test in days, $U_{m}$ is the measured U-value of the wall, index $i$ indicates the number of the cycle and INT is the integer part.

\subsection{Analysis of Variability of Results}

The introduction of a PVC film during the monitoring process changes the theoretical U-value of the wall due to its inherent thermal resistance plus the thermal contact resistance between the film and the wall surface. The theoretical maximum thermal resistance associated with the inclusion of a PVC film is estimated according to Equations (1) and (2), as follows:

$$
R_{\text {film_max }}\left(\frac{m^{2} \cdot K}{W}\right)=0.0005+\frac{15 \cdot 10^{-6}}{0.12}=6.25 \cdot 10^{-4}
$$

where the thermal contact resistance is usually between 0.000005 to $0.00005 \mathrm{~m}^{2} \cdot \mathrm{K} / \mathrm{W}$ according to Çengel and Ghajar [57], the thickness of the film is usually between $7 \times 10^{-6}$ to $15 \times 10^{-6} \mathrm{~m}$, the thermal conductivity of the material is between 0.12 to $0.25 \mathrm{~W} / \mathrm{m} \cdot \mathrm{K}$ and $R_{\text {film_max }}$ is the maximum thermal resistance associated to the inclusion of a PVC film, considering the most insulation case of the film inclusion.

The theoretical effect of the inclusion of a PVC film on the thermal transmittance is calculated according to Equation (1) for the two case studies and shown in Table 4 . The deviations between the theoretical thermal transmittance (NF) and the thermal transmittance when using a PVC film during the installation of the heat flow meter (F) are practically imperceptible values, $0.14 \%$ in Case study 1 and $0.02 \%$ in Case study 2.

Table 4. Theoretical impact of the inclusion of a PVC film on the thermal transmittance in the two

\begin{tabular}{|c|c|c|c|}
\hline Case Study & $\begin{array}{c}\text { Theoretical U-Value } \\
\text { NF }\left(\mathrm{W} / \mathrm{m}^{2} \cdot \mathrm{K}\right)\end{array}$ & $\begin{array}{l}\text { Theoretical U-Value F } \\
\left(\mathrm{W} / \mathrm{m}^{2} \cdot \mathrm{K}\right)\end{array}$ & $\begin{array}{c}\text { Deviation between } \\
\text { U-Values(\%) }\end{array}$ \\
\hline Case study 1 & 2.20 & 2.19 & 0.14 \\
\hline Case study 2 & 0.36 & 0.36 & 0.02 \\
\hline
\end{tabular}
case studies.

To assess the use of a protective film during the installation of heat flow meters, two values of the measured thermal transmittance were calculated for each case study. The first value was obtained using a heat flow meter plate installed with a layer of thermal interface material directly on the wall surface $\left(U_{m N F}\right)$ and the second value was obtained using a heat flow meter plate installed with a PVC film between the layer of thermal interface material and the wall $\left(U_{m F}\right)$. To check the adjustment between both measured U-values, the absolute value of the relative difference between measured U-values were calculated using the following expression:

$$
\text { Absolute value of the relative difference } U_{m N F}-U_{m F}(\%)=\left|\frac{\left(U_{m N F}-U_{m F}\right)}{U_{m} N F} \times 100\right|
$$

where $U_{m N F}$ is the measured U-value of the wall using the dynamic method using an HFM installed without film and $U_{m F}$ is the measured U-value of the wall using the dynamic method using an HFM installed with a PVC film between the layer of thermal interface material and the wall.

The variability of results was analysed by comparing the relative difference between the measured thermal transmittances obtained according to Equation (7), with the theoretical effect of including a PVC during the monitoring process shown in Table 4. 


\section{Results}

The data acquisition process was conducted following the indications in Section 2, with a sampling duration of $168 \mathrm{~h}$ in Case study 1 (337 readings) and of $144 \mathrm{~h}$ in Case study 2 (289 readings). Two measured thermal transmittances and its confidence interval were calculated, for 24-h test cycles using the dynamic method in the two case studies [54]. One value was calculated using data from the heat flow meter plate installed with a layer of thermal interface material directly on the wall surface and the other value was calculated using data from the heat flow meter installed with a PVC film between the layer of thermal interface material and the wall.

The minimum test duration was checked considering the ISO standard [31]. The first requirement is that the sampling duration must be an integer of $24 \mathrm{~h}$ and at least $72 \mathrm{~h}$ (Equation (3)). Consequently, the second and third requirements were verified from the third day onwards. The second requirement for test completion is that the value of thermal transmittance obtained at the end of the sampling duration shall not deviate more than $5 \%$ from the value obtained $24 \mathrm{~h}$ before (Equation (4)). In accordance with this condition, in Case studies 1 and 2 the test could be ended after $72 \mathrm{~h}$, as the requirement was met for all cycles with both HFM installation methods. The last requirement for ending the test is that the U-value obtained by analysing data from the first $2 / 3$ of the sampling duration shall not deviate more than $5 \%$ from the value obtained from the data for the last period of the same length (Equation (5)). According to this condition, in Case study 1 the monitoring process could be ended in $96 \mathrm{~h}$ using an HFM installed directly on the wall surface and in $120 \mathrm{~h}$ when an HFM was used with a PVC film between the layer of thermal interface material and the wall surface. In Case study 2, the test could be stopped at $72 \mathrm{~h}$ when the heat flow meter was installed directly on the wall surface and in $120 \mathrm{~h}$ when the heat flow meter was installed with a PVC film between the layer of thermal interface material and the wall surface. The minimum test duration when using an HFM installed directly on the wall surface was found to be shorter than when using an HFM installed with a PVC film between the layer of thermal interface material and the wall surface.

The results of the measured thermal transmittance for the two case studies are shown in Table 5 and depicted in Figure 4 , where $U_{m-D y n} \pm 195 \%$ is the measured U-value using the dynamic method, $H F M_{N F}$ indicates the use of a heat flow meter plate installed with a layer of thermal interface material directly on the wall surface and $H F M_{F}$ indicates the use of a heat flow meter installed with a PVC film between the layer of thermal interface material and the wall.

Table 5. Measured thermal transmittance values using the dynamic method in 24-h cycles, using an HFM installed with a layer of thermal interface material directly on the wall surface $\left(H F M_{N F}\right)$ and an HFM installed with a PVC film between the layer of thermal interface material and the wall surface $\left(H F M_{F}\right)$.

\begin{tabular}{|c|c|c|c|c|}
\hline \multirow{3}{*}{$\begin{array}{l}\text { Duration of the } \\
\text { Test (h) }\end{array}$} & \multirow{2}{*}{\multicolumn{2}{|c|}{$\begin{array}{c}\text { Case Study } 1 \\
\mathrm{U}_{\mathrm{m}-\mathrm{Dyn}} \pm \mathrm{I}_{95 \%}\left(\mathrm{~W} / \mathrm{m}^{2} \cdot \mathrm{K}\right)\end{array}$}} & \multicolumn{2}{|c|}{ Case Study 2} \\
\hline & & & \multicolumn{2}{|c|}{$\mathrm{U}_{\mathrm{m}-\mathrm{Dyn}} \pm \mathrm{I}_{95 \%}\left(\mathrm{~W} / \mathrm{m}^{2} \cdot \mathrm{K}\right)$} \\
\hline & HFM $_{\mathrm{NF}}$ & HFM $_{F}$ & HFM $_{\mathrm{NF}}$ & HFM $_{F}$ \\
\hline $24 \mathrm{~h}$ & $2.19 \pm 0.12$ & $2.03 \pm 0.10$ & $0.34 \pm 0.02$ & $0.27 \pm 0.02$ \\
\hline $48 \mathrm{~h}$ & $2.21 \pm 0.10$ & $1.62 \pm 0.05$ & $0.35 \pm 0.01$ & $0.28 \pm 0.01$ \\
\hline $72 \mathrm{~h}$ & $2.25 \pm 0.09$ & $1.64 \pm 0.05$ & $0.35 \pm 0.01$ & $0.27 \pm 0.01$ \\
\hline $96 \mathrm{~h}$ & $2.24 \pm 0.06$ & $1.69 \pm 0.03$ & $0.34 \pm 0.01$ & $0.27 \pm 0.01$ \\
\hline $120 \mathrm{~h}$ & $2.24 \pm 0.05$ & $1.70 \pm 0.03$ & $0.35 \pm 0.01$ & $0.28 \pm 0.01$ \\
\hline $144 \mathrm{~h}$ & $2.23 \pm 0.04$ & $1.70 \pm 0.02$ & $0.35 \pm 0.01$ & $0.28 \pm 0.01$ \\
\hline $168 \mathrm{~h}$ & $2.24 \pm 0.04$ & $1.70 \pm 0.02$ & - & - \\
\hline
\end{tabular}


(a1)

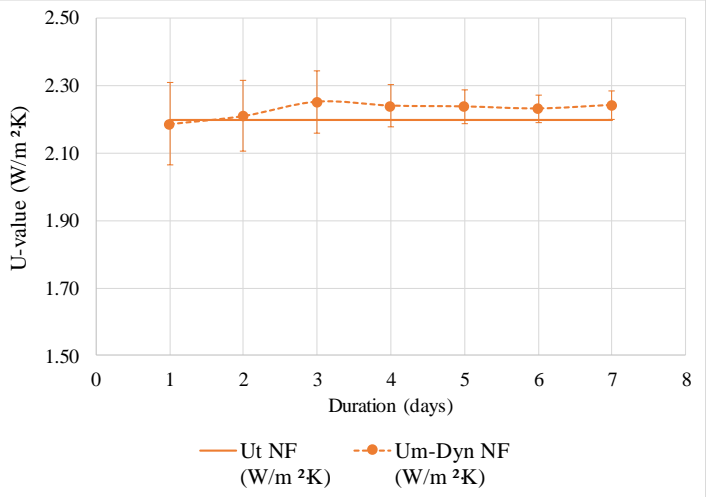

(b1)

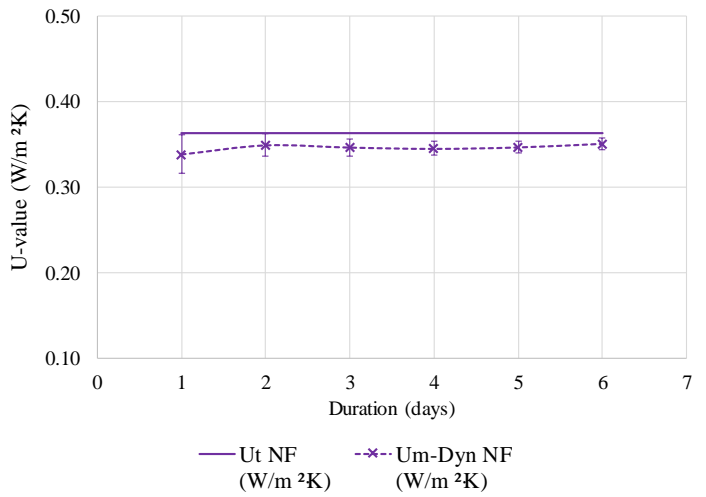

(a2)

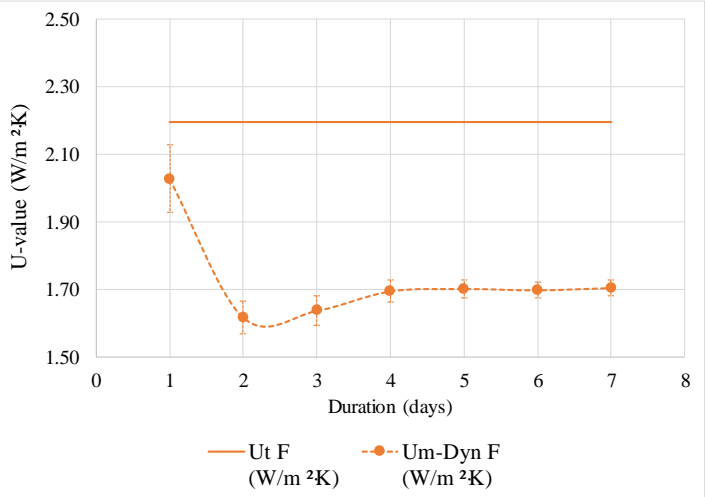

(b2)

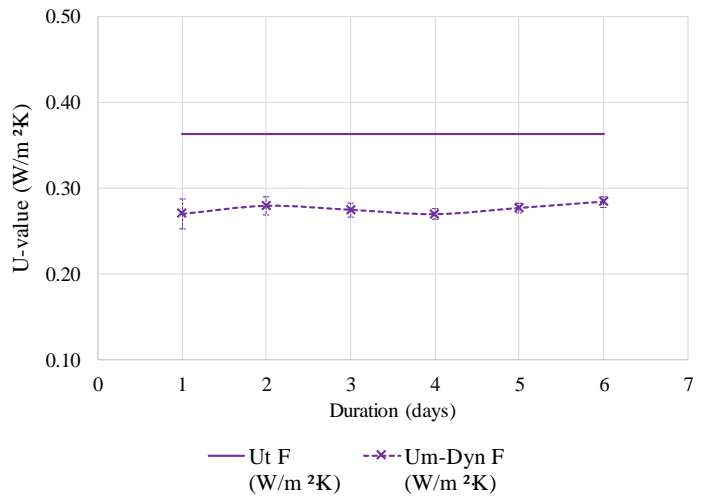

Figure 4. Theoretical and measured thermal transmittance values, (1) using an HFM installed with a layer of thermal interface material directly on the wall surface (NF) and, (2) an HFM installed with a PVC film between the layer of thermal interface material and the wall surface (F) for (a) Case study 1 and (b) Case study 2.

As tests lengthened, the confidence intervals were reduced. These findings are aligned with those analysed in the existing literature, in which the length of the test that was too short led to greater confidence intervals [14,37].

Deviations between the two measured thermal transmittance values were calculated following Equation (7), using an HFM installed with a layer of thermal interface material directly on the wall surface and an HFM installed with a PVC film between the layer of thermal interface material and the wall surface. These relative differences between measured U-values using both heat flow meters for the two case studies are depicted in Figure 5 and summarised in Table 6.

Table 6. Influence of using a PVC film between the layer of thermal interface material and the wall surface on the in situ measurement of the thermal transmittance in the two case studies.

\begin{tabular}{ccc}
\hline \multirow{2}{*}{ Duration of the Test (h) } & \multicolumn{2}{c}{$\mathrm{I} \frac{\left(U_{q N F}-U_{q F}\right)}{U_{q N F}} \mid \mathbf{~ ( \% )}$} \\
\cline { 2 - 3 } & Case Study 1 & Case Study 2 \\
\hline $24 \mathrm{~h}$ & 7.27 & 20.17 \\
$78 \mathrm{~h}$ & 26.81 & 20.01 \\
$72 \mathrm{~h}$ & 27.27 & 20.70 \\
$96 \mathrm{~h}$ & 24.33 & 21.74 \\
$120 \mathrm{~h}$ & 23.94 & 20.13 \\
$144 \mathrm{~h}$ & 23.91 & 19.09 \\
\hline
\end{tabular}




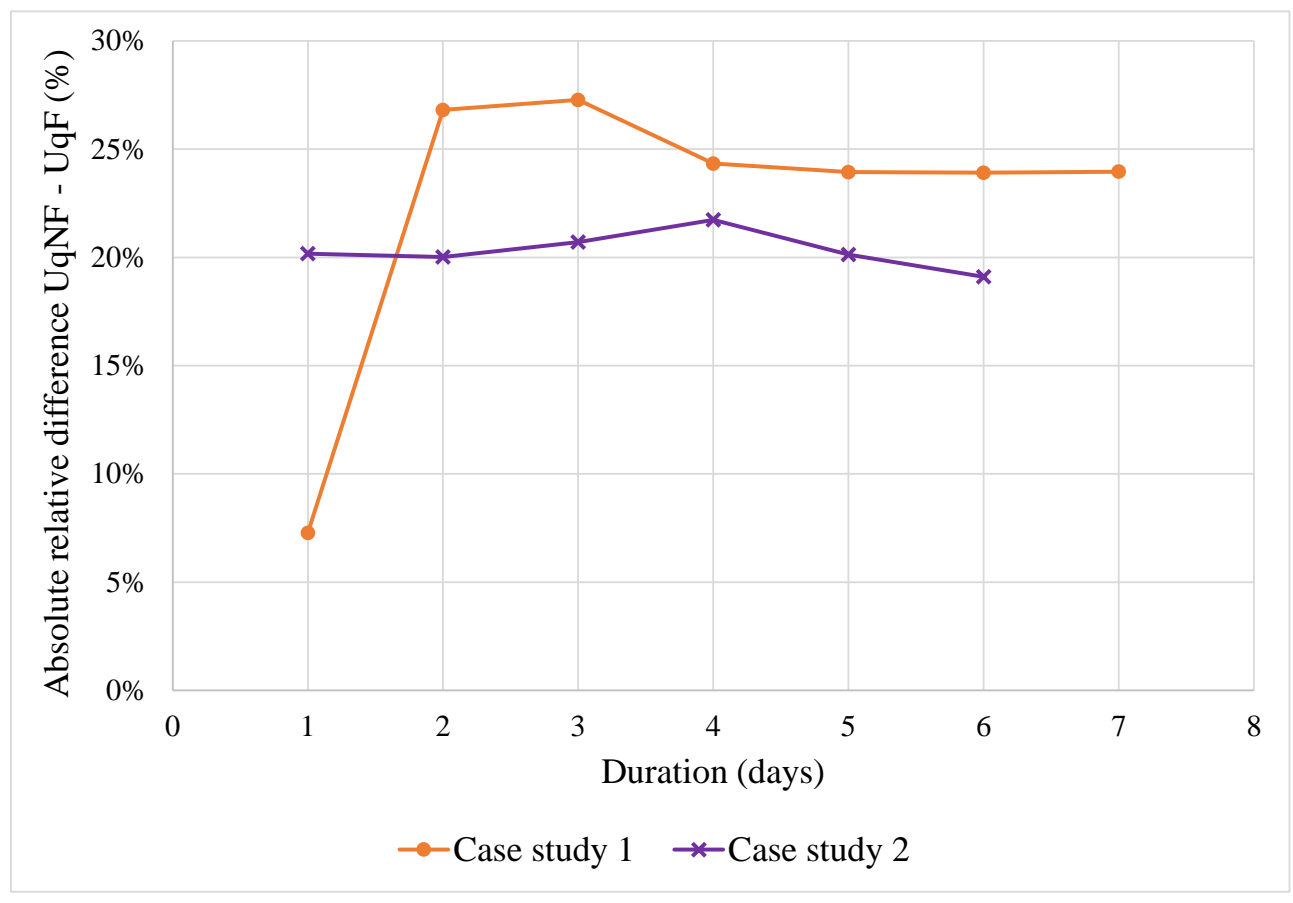

Figure 5. Deviation between the measured thermal transmittances for the two case studies, using an HFM installed with a layer of thermal interface material directly on the wall surface and an HFM installed with a PVC film between the layer of thermal interface material and the wall surface.

\section{Discussion and Conclusions}

This research assesses the influence of the heat flow meter plate non-perfect thermal contact on the accuracy of the in situ measurement of walls' thermal transmittance using the standardised heat flow meter method. The assessment considers usual practices in the installation of heat flow meters, consisting of the application of a PVC film to avoid damage to the wall in occupied buildings, in two case studies with different theoretical thermal transmittance values. The experimental campaign was designed to isolate measurement errors related to non-perfect thermal contact from those related to the measurement accuracy and the analysis of data. In situ measurements were conducted in the same conditions and equipment, with two heat flow meters: one was carefully installed with a layer of thermal interface material directly on the wall surface and the other was carefully installed by applying a film between the thermal interface material and the wall. Data were analysed in 24-h periods using the dynamic method. Finally, the variability of results was analysed by comparing the deviation between the measured thermal transmittances obtained from the two heat flow meters with the theoretical effect of including a PVC film during the monitoring process.

Test completion results indicate that the minimum duration of experimental campaigns was influenced by the installation of the heat flow meter plate. Generally, when the heat flow meter was installed by applying a PVC film between the thermal interface material and the wall to protect its surface, the minimum duration of the test was longer than when the heat flow meter was directly installed on the wall surface without a PVC film. In Case study 1, the test lasted $24 \mathrm{~h}$ more and in Case study 2, the test lasted $48 \mathrm{~h}$ more.

The findings show that the use of a PVC film hinders the installation of sensors, worsening the thermal contact between sensor and wall. Relative differences between the measured U-values were found to be greater than the expected by the theoretical calculation and also by the ISO standard quantification in both case studies. Deviations between the two measured thermal transmittance values, using an HFM installed with a layer of thermal interface material directly on the wall surface and an HFM installed 
with a PVC film between the layer of thermal interface material and the wall surface, were found to be significantly different than those expected resulting from the calculation of the theoretical effect of including a PVC during the monitoring process summarised in Table 4. In the theoretical estimation, the use of a PVC film between the layer of thermal interface material and the wall surface had an expected deviation of $0.14 \%$ in Case study 1 and $0.02 \%$ in Case study 2. However, in the experimental tests results from the third cycle onwards showed that for Case study 1, the relative differences were around $24 \%$ to $27 \%$, and in Case study 2 around $19 \%$ to $21 \%$. On the other hand, random variations caused by a non-perfect thermal contact between the sensors and the surface are quantified by $5 \%$ according to ISO 9869-1:2014 [31]. The experimental results also differ significantly from those quantified by ISO standard [31]. These considerable differences between the expected differences and the measured ones might be due to collateral effects when installing an HFM with a PVC film between the layer of thermal interface material and the wall surface that hampers a good thermal contact, as Li et al. [27] suggested. Including a PVC film to protect the wall may complicate the sensor installation process and consequently, the quality of the thermal contact might be hampered. Additionally, the theoretical calculation of including a PVC film on the thermal transmittance does not consider random variations in the thermal contact of the HFM with the surface of the wall tested. Moreover, extending the duration of the test did not seem to reduce the differences between the measured U-values. Therefore, it is highly recommended to avoid the use of a PVC film between the layer of thermal interface material and the wall surface in the in situ measurement of the thermal transmittance of existing buildings' façades when accurate results are required.

This research could be useful for practitioners when they conduct energy audits. It was found that when HFMs were installed with a PVC film between the layer of thermal interface material and the wall surface, the measured thermal transmittance was around 19 to $27 \%$ lower than when HFMs were installed with a layer of thermal interface material directly on the wall surface. Therefore, depending on the installation of heat flow meter plates, technical staff could take into account these possible deviations in the in situ measurement of the façades' actual thermal transmittance during building's operational stage and, consequently, propose appropriate energy retrofitting strategies.

Author Contributions: Conceptualization, K.G., M.C. and M.G.; methodology, K.G., M.C. and M.G.; investigation, K.G., M.C. and M.G.; data curation, K.G.; writing-original draft preparation, K.G.; writing-review and editing, K.G., M.C. and M.G.; visualization, K.G.; supervision, M.C. and M.G.; project administration, M.C.; funding acquisition, M.C. All authors have read and agreed to the published version of the manuscript.

Funding: This research was partially funded by the Government of Catalonia, Research Grant 2017 -SGR-227.

Data Availability Statement: Not applicable.

Conflicts of Interest: The authors declare no conflict of interest. The funders had no role in the design of the study; in the collection, analyses, or interpretation of data; in the writing of the manuscript, or in the decision to publish the results. 


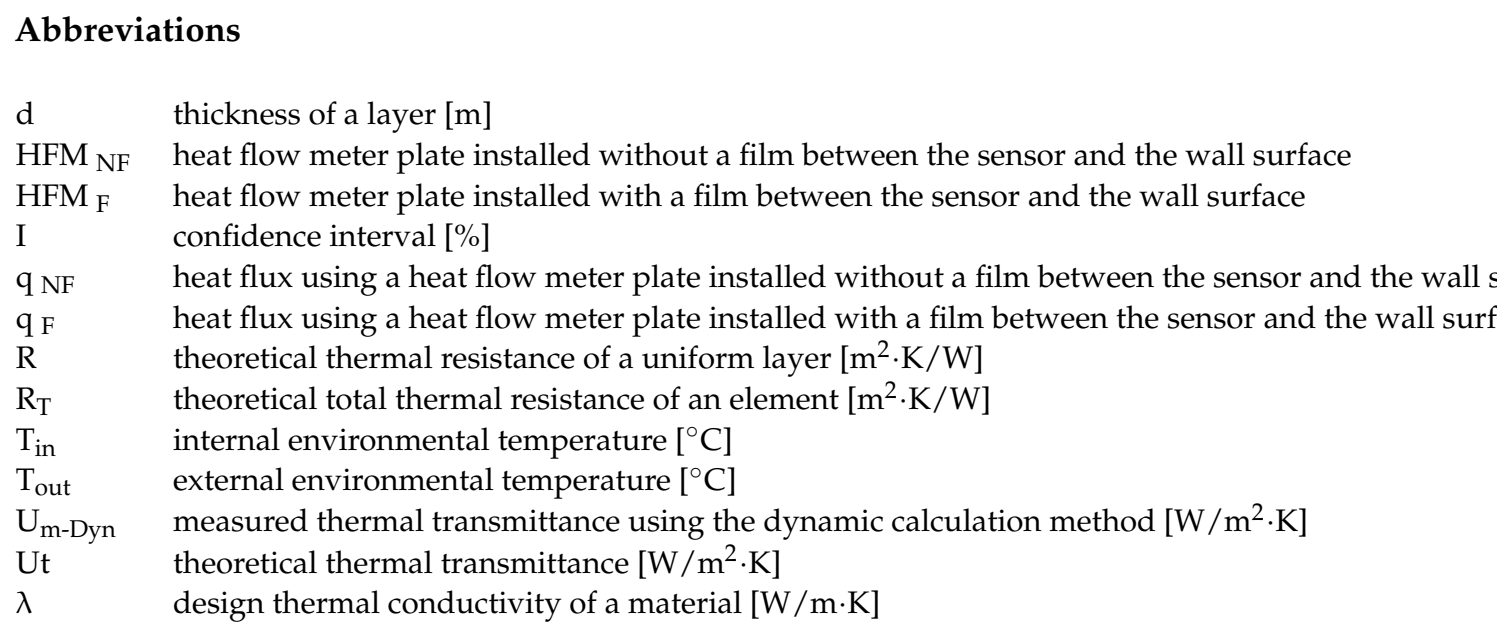

\section{References}

1. Martynov, A.; Sushama, L.; Laprise, R. Simulation of temperate freezing lakes by one-dimensional lake models: Performance assessment for interactive coupling with regional climate models. Boreal Environ. Res. 2010, 15, 143-164. [CrossRef]

2. Pedregosa, F.; Varoquaux, G.; Gramfort, A.; Michel, V.; Thirion, B.; Grisel, O.; Vanderplas, J. Scikit-learn: Machine Learning in Python. J. Mach. Learn. Res. 2012, 12, 2825-2830. [CrossRef]

3. European Union. Directive (EU) 2018/844 of the European Parliament and of the Council of 30 May 2018 Amending Directive 2010/31/EU on the Energy Performance of Buildings and Directive 2012/27/EU on Energy Efficiency. 2018. Available online: https:/ / eur-lex.europa.eu/legal-content/EN/TXT/PDF/?uri=CELEX:32018L0844\&from=EN (accessed on 24 October 2019).

4. Buildings Performance Institute Europe (BPIE). 97\% of Buildings in the EU Need To Be Upgraded. 2017. Available online: http:/ / bpie.eu/publication/97-of-buildings-in-the-eu-need-to-be-upgraded/ (accessed on 3 September 2020).

5. European Commission. Communication from the Commission to the European Parliament, the Council, the European Economic and Social Committee and the Committee of the Regions. A Renovation Wave for Europe-Greening Our Buildings, Creating Jobs, Improving Lives. COM(2020) 662 Final. Available online: https:/ / eur-lex.europa.eu/resource.html?uri=cellar:0638aa1d-0f0 2-11eb-bc07-01aa75ed71a1.0003.02/DOC_1\&format=PDF (accessed on 21 October 2020).

6. European Union. EU Energy in Figures; Publications Office of the European Union: Luxembourg, 2020.

7. Government of Spain. 2017-2020 National Energy Efficiency Action Plan; Government of Spain: Madrid, Spain, 2017 ; pp. 1-216.

8. Gangolells, M.; Casals, M.; Forcada, N.; Macarulla, M.; Cuerva, E. Energy mapping of existing building stock in Spain. J. Clean. Prod. 2016, 112, 3895-3904. [CrossRef]

9. Buildings Performance Institute Europe (BPIE). Europe's Buildings Under the Microscope; A Country-by-Country Review of the Energy Performance of Buildings; Buildings Performance Institute Europe (BPIE): Brussels, Belgium, 2011.

10. Roels, S. IEA EBC Annex 71: Building Energy Performance Assessment Based on In-Situ Measurements; EBC: Birmingham, UK, 2017.

11. Kampelis, N.; Gobakis, K.; Vagias, V.; Kolokotsa, D.; Standardi, L.; Isidori, D.; Cristalli, C.; Montagino, F.M.; Paredes, F.; Muratore, P.; et al. Evaluation of the performance gap in industrial, residential \& tertiary near-Zero energy buildings. Energy Build. 2017, 148, 58-73. [CrossRef]

12. Farmer, D.; Gorse, C.; Swan, W.; Fitton, R.; Brooke-Peat, M.; Miles-Shenton, D.; Johnston, D. Measuring thermal performance in steady-state conditions at each stage of a full fabric retrofit to a solid wall dwelling. Energy Build. 2017, 156, 404-414. [CrossRef]

13. Evangelisti, L.; Guattari, C.; Gori, P.; Asdrubali, F. Assessment of equivalent thermal properties of multilayer building walls coupling simulations and experimental measurements. Build. Environ. 2018, 127, 77-85. [CrossRef]

14. Asdrubali, F.; D’Alessandro, F.; Baldinelli, G.; Bianchi, F. Evaluating in situ thermal transmittance of green buildings masonries-A case study. Case Stud. Constr. Mater. 2014, 1, 53-59. [CrossRef]

15. Desogus, G.; Mura, S.; Ricciu, R. Comparing different approaches to in situ measurement of building components thermal resistance. Energy Build. 2011, 43, 2613-2620. [CrossRef]

16. Evangelisti, L.; Guattari, C.; Gori, P.; Vollaro, R.D.L. In Situ Thermal Transmittance Measurements for Investigating Differences between Wall Models and Actual Building Performance. Sustainability 2015, 7, 10388-10398. [CrossRef]

17. Ficco, G.; Iannetta, F.; Ianniello, E.; Alfano, F.R.D.; Dell'Isola, M. U-value in situ measurement for energy diagnosis of existing buildings. Energy Build. 2015, 104, 108-121. [CrossRef]

18. Hughes, M.; Palmer, J.; Cheng, V.; Shipworth, D. Sensitivity and uncertainty analysis of England's housing energy model. Build. Res. Inf. 2013, 41, 156-167. [CrossRef]

19. Sunikka-Blank, M.; Galvin, R. Introducing the prebound effect: The gap between performance and actual energy consumption. Build. Res. Inf. 2012, 40, 260-273. [CrossRef]

20. Symonds, P.; Taylor, J.; Mavrogianni, A.; Davies, M.; Shrubsole, C.; Hamilton, I.; Chalabi, Z. Overheating in English dwellings: Comparing modelled and monitored large-scale datasets. Build. Res. Inf. 2016, 45, 195-208. [CrossRef] 
21. Zheng, K.; Cho, Y.K.; Wang, C.; Li, H. Noninvasive Residential Building Envelope R-Value Measurement Method Based on Interfacial Thermal Resistance. J. Arch. Eng. 2016, 22, A4015002. [CrossRef]

22. Lucchi, E. Thermal transmittance of historical brick masonries: A comparison among standard data, analytical calculation procedures, and in situ heat flow meter measurements. Energy Build. 2017, 134, 171-184. [CrossRef]

23. Sassine, E. A practical method for in-situ thermal characterization of walls. Case Stud. Therm. Eng. 2016, 8, 84-93. [CrossRef]

24. Laaroussi, N.; Lauriat, G.; Garoum, M.; Cherki, A.; Jannot, Y. Measurement of thermal properties of brick materials based on clay mixtures. Constr. Build. Mater. 2014, 70, 351-361. [CrossRef]

25. Kumar, A.; Suman, B. Experimental evaluation of insulation materials for walls and roofs and their impact on indoor thermal comfort under composite climate. Build. Environ. 2013, 59, 635-643. [CrossRef]

26. Björk, F.; Enochsson, T. Properties of thermal insulation materials during extreme environment changes. Constr. Build. Mater. 2009, 23, 2189-2195. [CrossRef]

27. Li, F.G.N.; Smith, A.; Biddulph, P.; Hamilton, I.; Lowe, R.J.; Mavrogianni, A.; Oikonomou, E.; Raslan, R.; Stamp, S.; Stone, A.; et al. Solid-wallU-values: Heat flux measurements compared with standard assumptions. Build. Res. Inf. 2015, 43, 238-252. [CrossRef]

28. Roels, S. IEA EBC Annex 71: Building Energy Performance Assessment Based on Optimized In-Situ Measurements; EBC: Birmingham, $\mathrm{UK}, 2018$.

29. Bienvenido-Huertas, D.; Moyano, J.; Marín, D.; Fresco-Contreras, R.; Marín-García, D. Review of in situ methods for assessing the thermal transmittance of walls. Renew. Sustain. Energy Rev. 2019, 102, 356-371. [CrossRef]

30. Soares, N.; Martins, C.; Gonçalves, M.; Santos, P.; Da Silva, L.S.; Costa, J.J. Laboratory and in-situ non-destructive methods to evaluate the thermal transmittance and behavior of walls, windows, and construction elements with innovative materials: A review. Energy Build. 2019, 182, 88-110. [CrossRef]

31. International Organization for Standardization (ISO). Thermal Insulation-Building Elements-In-Situ Measurement of Thermal Resistance and Thermal Transmittance-Part 1: Heat Flow Meter Method; ISO Standard: Geneva, Switzerland, 2014.

32. Peng, C.; Wu, Z. In situ measuring and evaluating the thermal resistance of building construction. Energy Build. 2008, 40, 2076-2082. [CrossRef]

33. Janssens, A. IEA EBC Annex 58: Reliable Building Energy Performance Characterisation Based on Full Scale Dynamic Measurements; KU Leuven: Leuven, Belgium, 2016.

34. Trethowen, H. Measurement errors with surface-mounted heat flux sensors. Build. Environ. 1986, 21, 41-56. [CrossRef]

35. Meng, X.; Yan, B.; Gao, Y.; Wang, J.; Zhang, W.; Long, E. Factors affecting the in situ measurement accuracy of the wall heat transfer coefficient using the heat flow meter method. Energy Build. 2015, 86, 754-765. [CrossRef]

36. Albatici, R.; Tonelli, A.M.; Chiogna, M. A comprehensive experimental approach for the validation of quantitative infrared thermography in the evaluation of building thermal transmittance. Appl. Energy 2015, 141, 218-228. [CrossRef]

37. Nardi, I.; Ambrosini, D.; De Rubeis, T.; Sfarra, S.; Perilli, S.; Pasqualoni, G. A comparison between thermographic and flow-meter methods for the evaluation of thermal transmittance of different wall constructions. J. Phys. Conf. Ser. 2015, 655, 012007. [CrossRef]

38. Deconinck, A.-H.; Roels, S. Comparison of characterisation methods determining the thermal resistance of building components from onsite measurements. Energy Build. 2016, 130, 309-320. [CrossRef]

39. Atsonios, I.A.; Mandilaras, I.; Kontogeorgos, D.A.; Founti, M.A. A comparative assessment of the standardized methods for the in-situ measurement of the thermal resistance of building walls. Energy Build. 2017, 154, 198-206. [CrossRef]

40. Cesaratto, P.G.; De Carli, M.; Marinetti, S. Effect of different parameters on the in situ thermal conductance evaluation. Energy Build. 2011, 43, 1792-1801. [CrossRef]

41. Ahmad, A.; Maslehuddin, M.; Al-Hadhrami, L.M. In situ measurement of thermal transmittance and thermal resistance of hollow reinforced precast concrete walls. Energy Build. 2014, 84, 132-141. [CrossRef]

42. Guattari, C.; Evangelisti, L.; Gori, P.; Asdrubali, F. Influence of internal heat sources on thermal resistance evaluation through the heat flow meter method. Energy Build. 2017, 135, 187-200. [CrossRef]

43. Tadeu, A.; Simões, N.; Simões, I.; Pedro, F.; Škerget, L. In-Situ Thermal Resistance Evaluation of Walls Using an Iterative Dynamic Model. Numer. Heat Transf. Part A Appl. 2014, 67, 33-51. [CrossRef]

44. Gori, V.; Elwell, C.A. Estimation of thermophysical properties from in-situ measurements in all seasons: Quantifying and reducing errors using dynamic grey-box methods. Energy Build. 2018, 167, 290-300. [CrossRef]

45. Biddulph, P.; Gori, V.; Elwell, C.A.; Scott, C.; Rye, C.; Lowe, R.J.; Oreszczyn, T.; Oreszczyn, T. Inferring the thermal resistance and effective thermal mass of a wall using frequent temperature and heat flux measurements. Energy Build. 2014, 78, 10-16. [CrossRef]

46. Gaspar, K.; Casals, M.; Gangolells, M. Classifying System for Façades and Anomalies. J. Perform. Constr. Facil. 2016, 30, 04014187. [CrossRef]

47. International Organization for Standardization. Building Components and Building Elements-Thermal Resistance and Thermal Transmittance-Calculation Method; ISO: Geneva, Switzerland, 2007.

48. Spanish Ministry of Housing; Instituto de Ciencias de la Construcción Eduardo Torroja (IETcc). Constructive Elements Catalogue of Technical Building Code. 2010. Available online: https://www.codigotecnico.org/pdf/Programas/CEC/CAT-EC-v06.3_ marzo_10.pdf (accessed on 21 April 2020).

49. Tejedor, B.; Casals, M.; Macarulla, M.; Giretti, A. U-value time series analyses: Evaluating the feasibility of in-situ short-lasting IRT tests for heavy multi-leaf walls. Build. Environ. 2019, 159, 106123. [CrossRef] 
50. Tejedor, B.; Casals, M.; Gangolells, M. Assessing the influence of operating conditions and thermophysical properties on the accuracy of in-situ measured $U$-values using quantitative internal infrared thermography. Energy Build. 2018, 171, 64-75. [CrossRef]

51. Barreira, E.; Almeida, R.M.; Delgado, J.M.P.Q. Infrared thermography for assessing moisture related phenomena in building components. Constr. Build. Mater. 2016, 110, 251-269. [CrossRef]

52. Nardi, I.; Lucchi, E.; De Rubeis, T.; Ambrosini, D. Quantification of heat energy losses through the building envelope: A state-of-the-art analysis with critical and comprehensive review on infrared thermography. Build. Environ. 2018, 146, 190-205. [CrossRef]

53. Evangelisti, L.; Guattari, C.; Asdrubali, F. Influence of heating systems on thermal transmittance evaluations: Simulations, experimental measurements and data post-processing. Energy Build. 2018, 168, 180-190. [CrossRef]

54. Gaspar, K.; Casals, M.; Gangolells, M. A comparison of standardized calculation methods for in situ measurements of façades U-value. Energy Build. 2016, 130, 592-599. [CrossRef]

55. Roulet, C.; Gass, J.; Markus, I. In-Situ U-Value Measurement: Reliable Results in Shorter Time by Dynamic Interpretation of Measured Data. 1985. Available online: https://web.ornl.gov/sci/buildings/conf-archive/1985B3papers/057.pdf (accessed on 23 April 2020).

56. Gaspar, K.; Casals, M.; Gangolells, M. Review of criteria for determining HFM minimum test duration. Energy Build. 2018, 176, 360-370. [CrossRef]

57. Çengel, Y.A.; Ghajar, A.J. Heat and Mass Transfer: Fundamentals and Applications, 5th ed.; McGraw-Hill Education: New York, NY, USA, 2015. 